\title{
The implementation of Life Skills Oriented Education Through Learning Reorientation and School Reform on SMK
}

\author{
T. Sucita, Sumarto, J. P. Purba, B. Hasan \\ Department of Electrical Engineering \\ Universitas Pendidikan Indonesia \\ Bandung, Indonesia \\ tasmasucita@upi.edu
}

\begin{abstract}
This study aimed to achieving the implementation pattern of life skills education through a reorientation of learning and practice reforms implemented in vocational education. Research was conducted on vocational schools in West Java with a sample of five Schools. The method used in this study was quantitative research with descriptive problem-solving approach, associative causal and associative reciprocal. The objects of the research were vocational leaders, teachers of productive subjects, and students in grade 3 (XII) competency skills in Power Installation Engineering. The research findings show that learning in vocational education is in conformity with the goaloriented life skills. This is evidenced by the achievements in the implementation of the reorientation of the productive teacher. It shows a good significant support, and the reform of educational practices contribute to the achievement of the competence of graduates to achieve sufficient significance level. The achievement of the competency of students in grade 3 (XII) before graduating showed average figures is important in the provision of life skills to enter the workforce.
\end{abstract}

Keywords - life skills, learning reorientation, school reform

\section{INTRODUCTION}

Based on the observations of the everyday practice of education, formal education shows that education is focused so that students master the information contained in the subject matter and then evaluated by how much mastery was achieved by students. The learning process as if education is only intended to master the subjects only, while the relationship between the teaching material with daily life and the teaching materials that can be used to solve the problems of life have received less attention.

Vocational education aims to improve the ability of students to be able to develop themselves in line with the development of science, technology and vocational, as well as preparing students to enter the workforce and develop a professional attitude. Whatever type of vocational education at no other estuary of graduates so that they have the ability, skills and experts in the given field of science. Furthermore capable and skilled applied in the world of work. SMK intrinsic very different from public school or high school. There are two things actually excess of Vocational Secondary Education, the first graduates can fill job opportunities in business / industry, because it is associated with a certification that is owned by its graduates through Competency Test. Secondly, Vocational Education graduates can continue to pursue higher education, all graduates meet the requirements, both the value and study programs or departments in accordance with the required criteria. Even on development

SMK future will evolve in line with the government's desire to provide the opportunity for communities to set up schools so that no government policy to develop ratio SMK: SMA to 70: 30 in 2015 [1]. The existence of the policy of regional autonomy and decentralization of education finance then each region will compete to explore and develop the potential of their respective regions, including developing and exploiting the potential of human resources. The program is expected to improve the distribution of development in various sectors / fields throughout Indonesia.

Data and information relating to the absorption and the unemployment rate obtained from the BPS West Java Province [2] of the population and labor force unemployment by level of education in West Java province in 2012 can be explained as the following table.

TABLE I. POPULATION LABOR FORCE AND UNEMPLOYMENT (TPT) ACCORDING TO EDUCATION IN WEST JAVA.

\begin{tabular}{|c|c|c|c|c|c|c|}
\hline \multirow[t]{2}{*}{ Education } & \multicolumn{2}{|l|}{ Work } & \multicolumn{2}{|c|}{ Unemployment } & \multirow{2}{*}{$\begin{array}{l}\text { Total } \\
\text { (Persons) }\end{array}$} & \multirow{2}{*}{$\begin{array}{l}\text { TPT } \\
(\%)\end{array}$} \\
\hline & (Persons) & $(\%)$ & (Persons) & $(\%)$ & & \\
\hline$<=\mathrm{SD}$ & 8.928 .460 & 49,14 & 602.054 & 30,58 & 9.530 .514 & 6,32 \\
\hline SMP & 3.360 .773 & 18,50 & 499.600 & 25,37 & 3.860 .373 & 12,94 \\
\hline SMA Umum & 2.735 .322 & 15,05 & 411.890 & 20,90 & 3.147 .212 & 13.09 \\
\hline SMA Kejuruan & 1.656 .635 & 9,12 & 281.345 & 14,29 & 1.937 .980 & 14,52 \\
\hline Diploma I/II/III & 454.309 & 0,003 & 61.577 & 3,13 & 515.886 & 11,94 \\
\hline Universitas & 1.034 .153 & 5,69 & 112.540 & 5,71 & 1.146 .693 & 9.81 \\
\hline Total & 18.169 .652 & 100 & $1.969 .0 \%$ & 100 & $\begin{array}{l}20.138 .65 \\
8\end{array}$ & 9,78 \\
\hline
\end{tabular}

Based on the information above table shows that graduate education Vocational High School (SMK) has the highest unemployment rate is $15.52 \%$ or nearly two million $(1.93798$ million) soul. These events can be caused due to the 
reorientation of learning is done in schools has not led to life skills-oriented education. Life skills-oriented education ever launched by the government especially the Ministry of Education between 2003 and 2005 [3].

\section{Problem Formulation Research}

a. The plan for the implementation of life skills-oriented education as if that has been done on vocational competencies that have courses Power Installation Engineering Expertise?

b. How does the description of the competence of the students of SMK Class 3 (XII) study program Power Installation Engineering skills before they graduate and enter the workforce?

c. What is the relevance of learning undertaken in vocational courses that have Power Installation Engineering expertise to the objectives of the implementation of life skills-oriented education pattern?

\section{METHODS}

Description block diagram mapping (mapping) indicators variables / sub-variables.

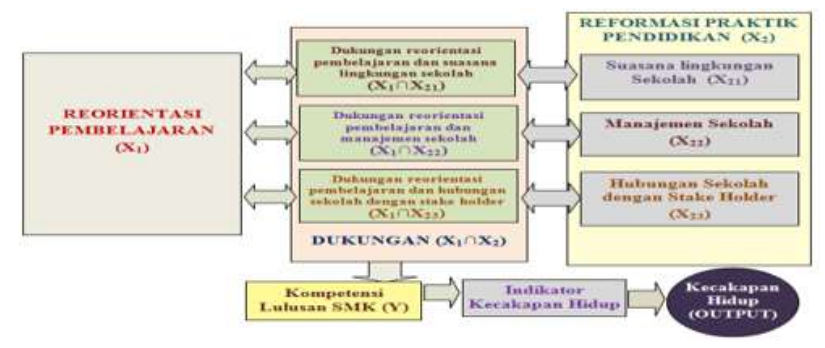

Fig. 1. Mapping indicators variables / sub variables of the study

Competence of vocational graduates is the dependent variable (Y) which influenced the results of the implementation of the reorientation of learning (X1) and the reform of educational practices (X2). Variable reform educational practices (X2) consists of three subvariable, the atmosphere of the school environment (X21), school management (X22), and school cooperation with stakeholders (X23).

Competence of vocational school graduates is a slice of three support groups: (1) support the reorientation of the learning atmosphere of the school environment, (2) support a reorientation of learning with school management, and (3) support the reorientation of the relationship between school learning with stakeholders. The third support that slice is produced graduates of vocational competence, which is then mapped through indicators of life skills as the output of the results of this study.

The sampling technique for the students is done by simple random sampling method with a total student average of 60 people (two classes) for each SMKN, and 34 (one class) for SMKS due to the limited number of students at the vocational school. Total samples involved in this study amounted to 345 people with the details of the leadership of SMK as many as 23 people, subject teachers earning 48 people, and students in grade 3 (XII) amounted to 274 people.

\section{RESULT AND DISCUSSION}

\section{A. A description of the conditions, facilities and} infrastructure SMK

In general, the facilities and infrastructure available in each vocational study sample is quite complete and very adequate for the creation of the implementation of competency-based learning in order to implement life skills-oriented education.

TABLE II. DESCRIPTION OF FACILITIES AND INFRASTRUCTURE INFORMATION SMK

\begin{tabular}{|c|c|c|c|c|c|c|}
\hline \multirow{2}{*}{ No. } & \multirow{2}{*}{$\begin{array}{l}\text { Fasility' } \\
\text { Infratemeture }\end{array}$} & \multicolumn{5}{|c|}{ Namo of SMK and Condition } \\
\hline & & SI:XND & SIXN T & SMINN $\mathbf{E}$ & SIXNZ & SMKS D \\
\hline I. & Tam Teth & $\begin{array}{l}\text { very } \\
\text { sociolined }\end{array}$ & $\begin{array}{l}\text { les: } \\
\text { socivilined }\end{array}$ & $\begin{array}{l}\text { very } \\
\text { socielized }\end{array}$ & $\begin{array}{l}\text { enough } \\
\text { socialived }\end{array}$ & $\begin{array}{l}\text { eroggh } \\
\text { rocilised }\end{array}$ \\
\hline 2. & Ruang OSTS & good & good & verygond & very good & enough \\
\hline 3. & $\begin{array}{l}\text { Aerjidi } \\
\text { Musbala }\end{array}$ & adequnte & adequxt: & very adequate & very dequzt? & wastable \\
\hline 4. & 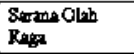 & siequare & reapure & vey adequare & very diequan & enough \\
\hline 5. & $\begin{array}{l}\text { Lab Praktik' } \\
\text { Woksthop }\end{array}$ & very & conirinate & $\begin{array}{l}\text { very } \\
\text { contribure }\end{array}$ & very & $\begin{array}{l}\text { vey } \\
\text { ontribute }\end{array}$ \\
\hline 6. & Ru.ng Kelas & good & enongh & very good & good & mogeh \\
\hline 7. & Libuary & xponloble & we? & arcaglable & axmisble & very gaod \\
\hline 8. & Lab Bahasa & not avploble & Dot2vinable & not axatable & 2valable & not winate \\
\hline 9. & $\begin{array}{l}\text { Comproter } \\
\text { laboratury }\end{array}$ & aszingble & me $x^{2}$ able & 2F्plable & $\begin{array}{l}\text { aralloble } \\
\text { (goodl) }\end{array}$ & $\begin{array}{l}\text { Erithble } \\
\text { (good) }\end{array}$ \\
\hline 10. & $\begin{array}{l}\text { Eoperasi } \\
\text { weloolah }\end{array}$ & avalable & washe & moilable & aviloble & marlable \\
\hline 11. & Iob fir & 20:mble & wathe & afailabl 1 & 2vinghle & $\begin{array}{l}\text { axathbly } \\
\text { (pond) }\end{array}$ \\
\hline 12. & LEK & xvilsble & Nathise & araibly & winghle & watably \\
\hline 13. & MoU & $\begin{array}{l}\text { local notional } \\
\text { mod } \\
\text { interartionol }\end{array}$ & $\begin{array}{l}\text { indutry locel } \\
\text { ad notionsl }\end{array}$ & $\begin{array}{l}\text { locel norional } \\
\text { ad } \\
\text { ixtenonional }\end{array}$ & $\begin{array}{l}\text { local } \\
\text { notional and } \\
\text { internationol }\end{array}$ & 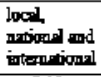 \\
\hline 14. & $\begin{array}{l}\text { Commintux } \\
\text { soom }\end{array}$ & aviloble & monshe & moetable & avaloble & previlable \\
\hline 15. & $\begin{array}{l}\text { Selotetrit } \\
\text { Alumai }\end{array}$ & 2xiloble & wathe & arathble & 202nable & axatiable \\
\hline
\end{tabular}

Facilities and infrastructure available in each vocational study samples, have shown very supportive to the attainment of the creation process oriented learning life skills well, because in terms of facilities and infrastructure available is almost complete and adequate. Some things that need attention with regard to the infrastructure that is necessary to increase dissemination and implementation of rules and regulations regarding school more serious, especially in SMKN T. It should provide lab facilities following English instructors to improve the competence of vocational students. SMK also cooperation with stakeholders is more intense, since there are many students have difficulty in carrying out the practice in the industry. Result of this research relevan with goal of development education in West Java [1].

\section{B. Description of vocational school students' perceptions of} grade 3 (XII) on the achievements of the competence of graduates of the life skills-oriented education.

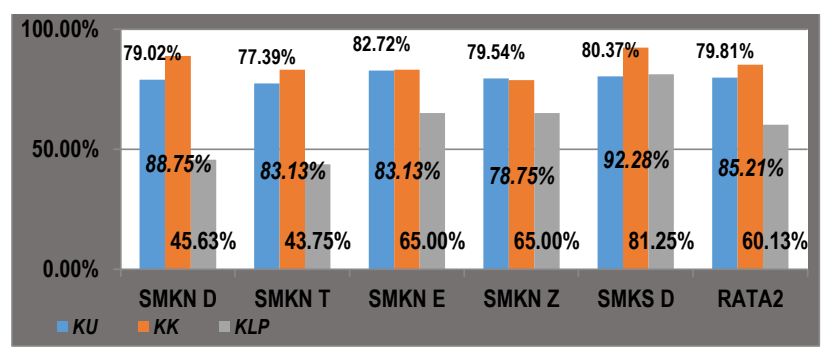

Fig. 2. Graph third comparative competence of graduates 
Descriptions and information shown on the picture above, explain the advantages and shortcomings of each vocational samples. the achievement of general competence almost evenly to all CMS, the highest shown by SMKN E (82.72\%), and the lowest was SMKN T (77.39\%). Vocational competencies obtained the highest number SMKS D (92.28\%), and the smallest SMKN Z (78.75\%). While the employment of competence lowest number SMKN T (43.75\%), and the highest SMKS D (81.25\%).

Pattern implementation of education related to life skills orientation of each sample in the form of vocational learning by using a reference implementation of the curriculum in 2006 that competency-based KTSP curriculum. achievement of competence are divided into three groups, namely general competencies competencies, vocational competencies and job competencies. This result describe about development curriculum in reference [4]. Output skills acquired prior to graduating students should be proven through the certification of competencies acquired through competency skills test held each SMK in collaboration with professional certification agency associated with the program the expertise possessed by SMK concerned. Currently some samples SMK still not fully carry out these activities, so not all vocational school graduates have a certificate of competence. Even if the student already has a certificate but it is still not specific and can not be fully recognized by the world of work.

\section{Life Skills-Oriented Education System}

Findings models oriented education system through the reorientation of learning life skills and practical reforms in vocational education can be described in the following figure.

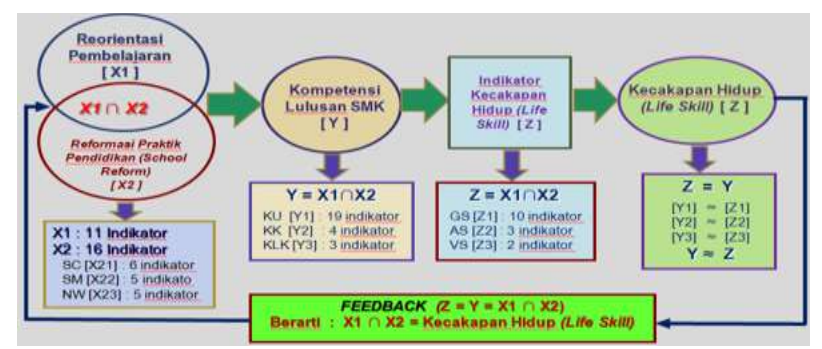

Fig. 3. Model of life skills-oriented education system

Model results of this study, can explain the whole of the system implementation of education-oriented life skills (life skills) at SMK obtained by using sample in five vocational school in the region Education Department of West Java Province which has a course competency skills Mechanical Power Installation. Result of this model support to goal of team BBE about explanation concept of education based of life skill [3]. The data was the final model of vocational samples can be described the following table.
TABLE III. THE DATA WAS THE FINAL MODEL OF THE FIVE VOCATIONAL SAMPLES

\begin{tabular}{|c|c|c|c|c|c|c|c|c|c|c|c|c|}
\hline SMK SAUPEL & $x_{1}$ & $x_{2}$ & $x_{1} \cap x_{2}$ & Y & $2=x_{1} \cap x_{i}$ & $\mathrm{KH}[2]$ & $I_{x 10}$ & $T(x \times 18)$ & $r_{A}$ & $K H=r_{R D}$ & \multicolumn{2}{|c|}{ SEUSH $(\gamma-Z)$} \\
\hline SWKNO & 79005 & $48.49 \%$ & $61.25 \%$ & $75.97 \%$ & $61.25 \%$ & $61.2 \%$ & 06233 & 097\% & 0,623 & 0.223 & $1472 \%$ & 0342 \\
\hline SUKNT & $5250 \%$ & $5607 \%$ & $5354 \%$ & $73.79 \%$ & $5354 \%$ & $5354 \%$ & 06180 & 0.971 & 0,6189 & 06180 & $2025 \%$ & 0,3521 \\
\hline SUKNE & $7000 \%$ & $65.00 \%$ & $67.50 \%$ & $02.49 \%$ & $67.5 \%$ & $67.50 \%$ & 09055 & 0.9754 & 0.8054 & 0.8654 & $1296 \%$ & 0.1700 \\
\hline SuKN Z & $88.00 \%$ & $7607 / 5$ & $81.46 \%$ & $77.56 \%$ & $81.45 \%$ & $81.45 \%$ & 09400 & 09904 & 09480 & 09480 & $390 \%$ & 0.0414 \\
\hline SMiks D & 82945 & $6218 \%$ & $69.30 \%$ & $8202 \%$ & $60.36 \%$ & $63.38 \%$ & 0.3517 & 0.9579 & 0.3517 & 0.3517 & 18645 & 0.6062 \\
\hline RATA2 & $74.4 \%$ & $61.56 \mathrm{x}$ & $65.45 \%$ & $7.95 \%$ & $65.49 \%$ & $66.43 \%$ & 0.6713 & 09740 & 0.6713 & 0.8718 & $126 \%$ & 0.3028 \\
\hline
\end{tabular}

Based on the table above, shows the average achievement of competence of graduates of vocational high school students sampled by $77.96 \%$, while support learning reorientation and reform educational practices in supporting the achievement of the competence of vocational school graduates an average of only $65.43 \%$, so there is a difference of $12.53 \%$. Figure is an increase of $12.53 \%$ can be supported by the efforts of students themselves through self-learning, the discussion or ask friends or other people closely related to the competency of the student.

Competence of graduates (including three subkompetensi namely general competencies, vocational competence, and competence jobs) were obtained from the results of this study is the result of contributions from the reorientation of learning undertaken by teachers of subjects productive, supported by reform educational practices that are owned by the school the sample of this study, so that the learning process in accordance with the objectives of the curriculum is by reference to the standard curriculum SBC in 2006, because the curriculum in 2013 (kurtilas) for students in grade 3 (XII) 2014/2015 academic year is still in use.

\section{CONCLUSIONS}

1. Facilities and infrastructure to support the implementation of learning-oriented life skills possessed by SMK SMK respondent has met to support the creation of a conducive learning process.

2. Competence of the students grade 3 (XII) SMK sample, indicating the level of achievement in the category of good and ready to enter the working world.

3. The results of the implementation of the mapping (mapping) of each of the indicators is in the competence of graduates of vocational skills competency program Installation Engineering Power to the indicators to be achieved by the pattern of implementation of life skills-oriented education, it can be concluded that the implementation of the learning undertaken at SMK SMK sample, have demonstrated the suitability (relevance) for the purpose of implementation of life skills-oriented education. 


\section{REFERENCES}

[1] Hilman, A. (2011). Workshop Program Pengembangan Mutu SMK Se Jawa Barat, (1.Globalisasi, peluang dan tantangan; 2.Strategi membangun mutu di SMK; 3.Kesiapan SMK; 4.Revitalisasi Kompetensi Keahlian SMK; 5.Rekomendasi.)

[2] Lindawati. (2013). Pengaruh Pengetahuan Kewirausahaan Dan Persepsi Siswa tentang Wirausaha Terhadap Minat Berwirausaha (Survey pada Siswa Kelas XII SMK Negeri Di Kota Bandung). Perpustakaan UPI. Bandung.

[3] Tim BBE (2003). Konsep Pendidikan Berorientasi Kecakapan Hidup (Life Skill) Melalui Pendekatan Broad Based Education. Departemen Pendidikan Nasional.[online] terdapat :http://www.lifeskill.net.Email:info@lifeskill.net [April, 2003]

[4] Kementrian Pendidikan dan Kebudayaan. (2012). Pengembangan Kurikulum 2013. Departemen Pendidikan dan Kebudayaan. Jakarta 